\title{
Antimicrobial activity of essential oil s in the treatment of microorganisms involved in crohn disease
}

\author{
Silva A.C.M.'; Xavier A.C.C.'; Bezerra A.M.', Melo C.G.F.; Silva I.C.P.'; Neves H.J.P.
}

${ }^{1}$ Pharmacy and Biomedical Sciences students of the Academic Center Tabosa de Almeida ASCES-UNITA, Caruaru-PE, '² University Professor of the Academic Center Tabosa de Almeida ASCES-UNITA, Caruaru-PE.

\section{ABSTRACT}

Background: Crohn Disease (CD) is an inflammatory disease with unknown etiology that affects the gastrointestinal tract resulting in tissue damage having clinical symptoms like fever, abdominal pain, diarrhea, fatigue, weight loss and anemia leaving the patient imunodepressive causing risks of opportunistic infection. Recurrent infections in the gastrointestinal tract can also serve as a trigger for the onset of the syndrome. The treatment with medications can bring side effects and for this reason the present study evaluates the activity of the extract of Syzygium aromaticum (clove), on the most incident microorganisms proposing to display it as a possible alternative treatment for patients with this disease. Aim: To evaluate the antimicrobial activity of Syzygium aromaticum against the most common microorganisms involved in CD. Methods: $10 \mathrm{~mL}$ of crude extract of clove were obtained by distillation and later tested by antibiogram in clinical strains of Candida albicans, one of the microorganisms of higher incidence in the disease. Results: By adding the disks containing the extract colonies diluted in salina to 0.5 according to McFarland scale (approximately $1.5 \times 108 \mathrm{CFU} / \mathrm{ml}$ ) arranged in Sabouraud agar plates incubated at $96,8^{\circ} \mathrm{F}$ for 24 hours was observed the formation of $10 \mathrm{~mm}$ inhibition halos demonstrating the antimicrobial effect of the extract on Candida albicans colonies. Discussion: Several known medicines were obtained from natural sources, including consecrated antibiotics, demonstrating the importance of the study and application of natural products. Conclusion: The extract tested was considered efficient in its antifungal activity and new researches and confirmatory tests are necessary for this and other natural extracts so that they can be applied in the promotion of health causing fewer side effects and

*Correspondence to Author:

Neves H.J.P.

University Professor of the Academic Center Tabosa de Almeida ASCES-UNITA, Caruaru-PE

How to cite this article:

Silva A.C.M.; Xavier A.C.C.; Bezerra A.M., Melo C.G.F.; Silva I.C.P.; Neves H.J.P.Antimicrobial activity of essential oil $\mathrm{s}$ in the treatment of microorganisms involved in crohn disease.International Journal of Biomaterials and Nanobiotechnology. $2018,1: 5$

\section{eScîPub}

eSciPub LLC, Houston, TX USA.

Website: http://escipub.com/ at a lower cost.

Keywords: Crohn Desease; Natural Products; Microbiology 